\title{
KAJIAN STRATEGI KOPING DAN PERILAKU INVESTASI ANAK PADA KELUARGA BURUH PEMETIK MELATI GAMBIR
}

\author{
Umu Rosidah ${ }^{1}$, Hartoyo $^{1^{*}}$, Istiqlaliyah Muflikhati ${ }^{1}$ \\ ${ }^{1}$ Departemen IImu Keluarga dan Konsumen, Fakultas Ekologi Manusia, Institut Pertanian Bogor, \\ Bogor 16680, Indonesia \\ *) E-mail: hartoyo@ipb.ac.id
}

\begin{abstract}
Abstrak
Tujuan dari penelitian ini adalah untuk mengkaji strategi koping dan perilaku investasi anak pada keluarga buruh pemetik melati gambir. Lokasi penelitian dipilih secara purposive berdasarkan luas lahan melati gambir di lokasi penelitian. Penelitian ini melibatkan 66 keluarga yang terpilih secara acak. Data dikumpulkan dengan cara wawancara dan dianalisis menggunakan analisis regresi. Hasil penelitian menunjukkan bahwa istri sebagai buruh pemetik melati gambir memberikan kontribusi yang penting terhadap pendapatan keluarga. Berdasarkan Garis Kemiskinan, kesejahteraan keluarga dipengaruhi oleh pekerjaan tambahan suami, pekerjaan suami, pendidikan suami, dan pendapatan keluarga. Jumlah strategi koping yang dilakukan oleh keluarga termasuk dalam kategori sedikit. Besar keluarga, tipe keluarga, pekerjaan tambahan suami, dan kesejahteraan keluarga berpengaruh signifikan terhadap jumlah strategi koping. Pendidikan istri dan pendapatan keluarga berpengaruh signifikan terhadap perilaku investasi anak; besar keluarga, jumlah anak sekolah, pendidikan suami, tipe keluarga, dan pendapatan keluarga berpengaruh signifikan terhadap alokasi pengeluaran uang untuk anak.
\end{abstract}

Kata kunci: alokasi uang, investasi pendidikan, investasi kesehatan, kesejahteraan keluarga

\section{Study on Family Coping Strategy and Investment Behavior on Children of Jasmine officinale Labor Families}

\begin{abstract}
The objectives of this research were to investigate family coping strategy and the investment behavior on children of Jasmine officinale labor families. Research location was selected purposively based on size of Jasmine officinale area in study site. This research involved sixty six families were selected randomly. Data were collected by interview and were analyzed using regression analysis. The result of research showed that wife as Jasmine officinale labor gave important contribution to family income. Family welfare was influenced by father's side job, father's job, father's education, and family income. Coping strategies that were done by labor family was classified as low category. Family size, family type, father's side job, and family welfare has significant influence toward coping strategy. Mother's education and family income correlated significant with investment behavior; family size, number of school-age child, father's education, and family income had correlated significant with allocation of expenditure for children.
\end{abstract}

Keywords: allocation of expenditure, education investment, family welfare, health investment

\section{PENDAHULUAN}

Kualitas bangsa ditentukan oleh kualitas penduduk yang tercermin pada kualitas sumber daya manusia (SDM). Salah satu indikator kualitas penduduk adalah Human Development Index (HDI) yang menggambarkan kemampuan manusia dalam meningkatkan kesehatan, pendidikan, dan ekonomi. Berdasarkan data United Nation for Development Program (UNDP), HDI Negara Indonesia tahun 2010 menempati urutan ke-108 dari 169 negara di dunia. Rendahnya kualitas SDM akan berdampak terhadap pembangunan suatu bangsa yang diharapkan dapat meningkatkan kesejahteraan rakyat. Akan tetapi, dilihat dari segi ekonomi, jumlah penduduk miskin di Indonesia pada bulan Maret tahun 2010 mencapai 31,02 juta $(13,33 \%)$ dengan proporsi penduduk miskin paling banyak berasal dari keluarga petani (BPS, 2010). Salah satu contoh keluarga petani yang rentan dengan masalah kemiskinan adalah keluarga buruh pemetik melati gambir. Keluarga ini memiliki pendapatan yang rendah serta rentan terhadap fluktuasi harga dan perubahan musim.

$$
\text { Keluarga miskin banyak yang }
$$
menggantungkan hidupnya pada pekerjaan 
yang tidak tetap, upah yang rendah, tidak sehat, tidak aman, dan memiliki kesempatan yang rendah untuk memperbaiki kondisi hidup (CPRC, 2009). Ketika menghadapi masalah ekonomi, keluarga miskin melakukan suatu upaya agar kebutuhan anggota keluarga tetap terpenuhi. Keluarga miskin cenderung melakukan penghematan dibandingkan menambah pendapatan, strategi penghematan erat kaitannya dengan kemiskinan (Puspitawati, 1998). Strategi lain yang dapat digunakan adalah dengan mengandalkan sumber daya manusia yang ada, seperti anak-anak. Menurut Todaro dan Smith (2006), tingkat pendapatan yang rendah akan mendorong keluarga miskin untuk menambah anak karena anak dianggap sebagai tenaga kerja yang murah dan dapat dijadikan sandaran hidup di hari tua.

Anak adalah sumber daya berharga dan tahan lama. Keluarga dengan penghasilan tinggi akan mencurahkan lebih banyak sumber daya untuk meningkatkan kualitas anak (Hartoyo, 1998). Selain itu, anak adalah sumber daya untuk investasi. Bentuk investasi yang dapat diberikan adalah investasi di bidang pendidikan dan kesehatan. Tujuan investasi di bidang pendidikan adalah untuk meningkatkan pendapatan di masa yang akan datang dan tujuan investasi kesehatan adalah memperpanjang harapan hidup dan terhindar dari berbagai macam penyakit, sehingga memiliki waktu produktifitas yang tinggi. Menurut penelitian Edwards dan Grossman (1979), diacu dalam Bryant dan Zick (2006), status kesehatan berpengaruh terhadap perkembangan intelektual anak. Orang yang memiliki kesehatan baik akan memiliki waktu produktif yang lebih tinggi dan orang yang memiliki pendidikan tinggi akan memiliki pengetahuan yang lebih tinggi tentang kesehatan.

Pemaparan tersebut menunjukkan bahwa keluarga buruh pemetik melati gambir termasuk dalam keluarga miskin dan pendapatannya dihadapkan pada fluktuasi harga di satu sisi, sedangkan disisi lain adanya kebutuhan keluarga untuk bertahan hidup dan untuk meningkatkan SDM anggota keluarga. Dengan demikian, yang menjadi pertanyaan adalah berapa besar sebenarnya pendapatan keluarga mereka dari memetik melati gambir. Selanjutnya, jika pendapatan berkurang karena harga melati gambir turun bagaimana mengatasinya agar keluarga dapat memenuhi kebutuhan untuk pengembangan SDM terutama anak. Dengan demikian, penelitian ini dilakukan untuk menganalisis kontribusi istri terhadap pendapatan keluarga, tingkat kesejahteraan keluarga buruh pemetik melati gambir, strategi koping yang dijalankan oleh keluarga buruh pemetik melati gambir ketika pendapatan keluarga menurun (harga melati gambir murah), dan perilaku investasi anak yang dilakukan oleh keluarga buruh pemetik melati gambir. Selain itu, penelitian ini juga bertujuan untuk menganalisis variabel-variabel yang berpengaruh terhadap kesejahteraan keluarga, strategi koping, dan perilaku investasi anak pada keluarga buruh pemetik melati gambir.

\section{METODE}

Penelitian ini menggunakan desain cross sectional study. Lokasi penelitian adalah Desa Gelang, Kecamatan Rakit, Kabupaten Banjarnegara, Jawa Tengah. Penentuan lokasi dilakukan secara purposive karena Desa Gelang memiliki lahan melati gambir terluas di Kabupaten Banjarnegara. Pengambilan data dilakukan pada bulan April sampai dengan bulan Mei 2011.

Populasi dalam penelitian adalah keluarga buruh pemetik melati gambir yang memiliki anak sekolah (3-18 tahun) di Desa Gelang. Keluarga yang menjadi partisipan dalam penelitian ini (responden) berjumlah 66 keluarga yang dipilih secara simple random sampling.

Data yang dikumpulkan dalam penelitian ini meliputi karakteristik keluarga, kesejahteraan keluarga, strategi koping, dan perilaku investasi anak. Pengumpulan data dilakukan dengan teknik wawancara pada istri dengan menggunakan alat bantu kuesioner.

Karakteristik keluarga terdiri atas besar keluarga, usia suami dan istri, jumlah anak sekolah, pendidikan suami dan istri, pekerjaan suami, dan pendapatan keluarga. Besar keluarga diukur berdasarkan jumlah anggota keluarga dan dikategorikan dalam tiga kategori yaitu keluarga kecil ( $\leq 4$ orang), keluarga sedang (5-6 orang), dan keluarga besar ( $\geq 7$ orang). Jumlah anak sekolah dikategorikan dalam empat kategori yaitu satu anak, dua anak, tiga anak, dan empat anak. Pekerjaan suami dikategorikan dalam tujuh kategori yaitu tidak bekerja, wirausaha, pedagang, petani, buruh non-tani, buruh tani, dan jasa. Pendidikan suami dan istri diukur berdasarkan lama pendidikan formal yang telah ditempuh suami dan istri. Pendapatan keluarga diukur berdasarkan pendapatan per kapita per bulan. 
Kontribusi pendapatan buruh pemetik melati gambir terhadap pendapatan keluarga dihitung dengan cara membagi pendapatan buruh pemetik melati (rupiah) dengan total pendapatan keluarga (rupiah). Sementara itu, tingkat kesejahteraan keluarga buruh pemetik melati gambir dianalisis secara deskriptif berdasarkan indikator garis kemiskinan (GK) dan 14 kriteria penerima Bantuan Langsung Tunai (BLT). Berdasarkan indikator GK, keluarga yang memiliki penghasilan kurang dari atau sama dengan GK termasuk dalam keluarga miskin dan keluarga yang memiliki penghasilan lebih dari GK termasuk dalam keluarga tidak miskin. GK yang digunakan adalah garis kemiskinan Provinsi Jawa Tengah untuk daerah perdesaan tahun 2010 yaitu sebesar Rp179.982,00. Berdasarkan indikator Bantuan Langsung Tunai (BLT), keluarga yang memenuhi $\geq 11$ kriteria termasuk dalam kelompok miskin, keluarga yang memenuhi 910 kriteria termasuk dalam kategori hampir miskin, dan keluarga yang memenuhi $<9$ kriteria termasuk dalam kategori tidak miskin.

Strategi koping yang dijalankan oleh keluarga buruh pemetik melati gambir terjadi ketika terjadi penurunan pendapatan, terdiri atas dua kegiatan yaitu strategi menambah pendapatan (generating income) dan strategi mengurangi pengeluaran (cutting back) (Puspitawati, 1998). Instrumen yang digunakan untuk mengukur strategi koping merupakan modifikasi dari instrumen yang digunakan dalam penelitian Kusumo (2009). Data strategi koping diberi skor 1 untuk jawaban ya dan skor 0 untuk jawaban tidak. Strategi koping menambah pendapatan, mengurangi pengeluaran, dan strategi koping secara keseluruhan dikelompokkan menjadi tiga yaitu sedikit ( $\leq 14$ kegiatan), sedang (15-28 kegiatan), dan banyak ( $\geq 29$ kegiatan).

Perilaku investasi anak dihitung melalui perilaku investasi pendidikan, perilaku investasi kesehatan, dan alokasi pengeluaran (uang). Perilaku investasi pendidikan diartikan sebagai tindakan/perilaku yang dilakukan orang tua untuk menunjang pendidikan anak. Perilaku investasi kesehatan merupkan tindakan/ perilaku yang dilakukan oleh orang tua untuk menunjang kesehatan anak. Sementara itu, alokasi pengeluaran diartikan sebagai uang yang diberikan orang tua untuk menunjang pendidikan dan kesehatan anak. Instrumen yang digunakan telah reliabel dengan nilai Cronbach's alpha sebesar 0,861 (investasi pendidikan) dan 0,791 (investasi kesehatan).
Selanjutnya, skor yang diperoleh pada perilaku investasi dilakukan transformasi skor komposit dalam bentuk skala 0-100. Setelah dilakukan tranformasi skor komposit, perilaku investasi dikategorikan menjadi tiga kategori yaitu sedikit $(\leq 33,33 \%)$, sedang $(33,34 \%-66,66 \%)$ dan banyak $(\geq 66,66 \%)$.

Data yang telah dikumpulkan diolah dan dianalisis. Analisis deskriptif dilakukan untuk menghitung nilai rata-rata dan standar deviasi. Uji regresi logistik dilakukan untuk menganalisis variabel-variabel yang berpengaruh terhadap kesejahteraan keluarga. Sementara itu, uji regresi linear berganda dilakukan untuk menganalisis variabel-variabel yang berpengaruh terhadap jumlah strategi koping, perilaku investasi anak, dan alokasi pengeluaran untuk anak.

\section{HASIL}

\section{Karakteristik Keluarga}

Rata-rata jumlah anggota keluarga responden termasuk keluarga sedang (jumlah anggota keluarga 5-6 orang). Rata-rata usia suami adalah 44,05 tahun dan rata-rata usia istri adalah 39,38 tahun. Berdasarkan lama pendidikan, rata-rata pendidikan formal suami adalah 6,08 tahun dan istri selama 6,09 tahun. Keluarga responden memiliki rata-rata pendapatan keluarga sebesar Rp649.090,91/bulan. Rata-rata keluarga responden memiliki anak sekolah sebanyak dua orang. Sebagian besar keluarga responden memiliki suami yang bekerja di bidang pertanian baik sebagai petani maupun buruh tani.

Tabel 1 Kontribusi anggota keluarga terhadap pendapatan keluarga per bulan

\begin{tabular}{lrr}
\hline Sumber Pendapatan & \multicolumn{1}{c}{ Rupiah } & Persen \\
\hline Utama & & \\
Suami & $287.500,00$ & 44,30 \\
Istri & $134.015,15$ & 20,65 \\
Anak & $175.909,09$ & 27,10 \\
Jumlah & $597.424,24$ & 92,05 \\
\hline Tambahan & & \\
Suami & $15.303,03$ & 2,35 \\
Istri & $36.363,64$ & 5,60 \\
Anak & 0,00 & 0,00 \\
Jumlah & $51.666,67$ & 7,95 \\
\hline Total & & \\
Suami & $302.803,03$ & 46,65 \\
Istri & $170.378,79$ & 26,25 \\
Anak & $175.909,09$ & 27,10 \\
Jumlah & $649.090,91$ & 100,00 \\
\hline
\end{tabular}


Tabel 2 Sebaran keluarga berdasarkan status kesejahhteraan indikator GK dan BLT

\begin{tabular}{lrrrr}
\hline \multirow{2}{*}{ Indikator } & \multicolumn{2}{c}{ GK } & \multicolumn{2}{c}{ BLT } \\
\cline { 2 - 5 } & $\mathrm{n}$ & $\%$ & $\mathrm{n}$ & $\%$ \\
\hline Keluarga miskin & 47 & 71,21 & 0 & 0,00 \\
Keluarga tidak & 19 & 28,79 & 66 & 100,00 \\
miskin & & & & \\
Jumlah & 66 & 100,00 & 66 & 100,00 \\
\hline Keterangan: & \multicolumn{4}{l}{} \\
GK : Indikator garis kemiskinan \\
BLT : Kriteria rumah tangga miskin penerima BLT
\end{tabular}

\section{Kontribusi Istri terhadap Pendapatan Keluarga}

Proporsi terbesar pendapatan keluarga masih berasal dari suami baik dari pekerjaan utama maupun dari pekerjaan tambahan yaitu sebesar 46,65 persen/bulan. Proporsi pendapatan total istri dan anak terhadap pendapatan keluarga hampir sama yaitu 26,25 persen/bulan untuk istri dan 27,10 persen/bulan untuk anak (Tabel 1).

\section{Kesejahteraan Keluarga}

Berdasarkan indikator garis kemiskinan Provinsi Jawa Tengah untuk daerah perdesaan tahun 2010 , sebanyak 71,21 persen keluarga termasuk sebagai keluarga miskin. Sementara itu, berdasarkan indikator 14 kriteria rumah tangga miskin penerima BLT tidak terdapat keluarga yang termasuk sebagai keluarga miskin (Tabel 2).

Berdasarkan dua indikator yang telah digunakan untuk mengukur kesejahteraan keluarga di Desa Gelang, jumlah keluarga miskin berdasarkan indikator GK jauh lebih besar di bandingkan dengan indikator 14 kriteria rumah tangga miskin penerima BLT. Selanjutnya pada penelitian ini, penggolongan keluarga sebagai keluarga miskin diubah menjadi keluarga yang memenuhi lima indikator BLT, yang dijadikan sebagai ciri keluarga miskin pada keluarga buruh pemetik melati gambir di wilayah penelitian. Lima indikator yang dimaksud yaitu sumber air minum, bahan bakar memasak, kemampuan mengonsumsi daging/ayam/susu, sumber penghasilan Kepala Keluarga (KK), dan pendidikan KK.

Tabel 3 Sebaran keluarga berdasarkan strategi koping secara keseluruhan

\begin{tabular}{lcc}
\hline \multicolumn{1}{c}{ Kategori } & Jumlah & Persen \\
\hline Sedikit ( $\leq 14$ kegiatan) & 42 & 68,18 \\
Sedang (15-28 kegiatan) & 24 & 31,82 \\
Tinggi ( $\geq 29$ kegiatan) & 0 & 0,00 \\
\hline Total & 66 & 100,00 \\
\hline
\end{tabular}

\section{Strategi Koping}

Secara keseluruhan, dua dari tiga responden menilai bahwa strategi koping yang dilakukan oleh keluarganya termasuk kategori sedikit ( $\leq 14$ kegiatan) baik strategi mengurangi pengeluaran maupun strategi menambah pendapatan (Tabel 3). Strategi mengurangi pengeluaran yang paling banyak dilakukan keluarga responden adalah menunda pembelian barang elektronik, sedangkan strategi menambah pendapatan yang paling banyak dilakukan adalah dengan sengaja menerima makanan dari saudara atau tetangga.

\section{Perilaku Investasi Anak}

Perilaku investasi adalah tindakan yang dilakukan oleh orang tua untuk menunjang kegiatan anak yaitu pendidikan dan kesehatan. Berdasarkan skor total, perilaku investasi yang dilakukan 75,76 persen keluarga dalam penelitian ini termasuk dalam kategori sedang.

Perilaku Investasi Pendidikan. Hasil penelitian pada Tabel 4 menunjukkan bahwa sebagian besar keluarga memiliki investasi pendidikan dalam kategori sedang $(81,81 \%)$. Penelitian ini menemukan masih terdapat keluarga yang memiliki perilaku investasi pendidikan dalam kategori rendah $(10,60 \%)$.

Perilaku Investasi Kesehatan. Hasil penelitian menunjukkan bahwa perilaku investasi kesehatan yang dilakukan oleh 51,51 persen keluarga dalam penelitian ini termasuk dalam kategori sedang. Penelitian ini juga menemukan masih terdapat 46,96 persen keluarga yang memiliki perilaku investasi kesehatan dalam kategori rendah (Tabel 4).

Tabel 4 Sebaran keluarga berdasarkan perilaku investasi pendidikan dan kesehatan

\begin{tabular}{lrr}
\hline Kategori & Jumlah & Persen \\
\hline Investasi pendidikan & & \\
Rendah $(\leq 33,33 \%)$ & 7 & 10,60 \\
Sedang $(33,34 \%-66,66 \%)$ & 54 & 81,81 \\
Tinggi $(\geq 66,67)$ & 5 & 7,59 \\
Total & 66 & 100,00 \\
\hline Investasi kesehatan & & \\
Rendah $(\leq 33,33 \%)$ & 31 & 46,96 \\
Sedang $(33,34 \%-66,66 \%)$ & 34 & 51,51 \\
Tinggi $(\geq 66,67)$ & 1 & 1,53 \\
Total & 66 & 100 \\
\hline Perilaku Investasi total & & \\
Rendah $(\leq 33,33 \%)$ & 16 & 24,24 \\
Sedang $(33,34 \%-66,66 \%)$ & 50 & 75,76 \\
Tinggi $(\geq 66,67)$ & 0 & 0,00 \\
Total & 66 & 100,00 \\
\hline
\end{tabular}


Tabel 5 Alokasi uang untuk anak per bulan berdasarkan tingkat pendidikan anak

\begin{tabular}{lrrr}
\hline \multirow{2}{*}{ Kegiatan } & \multicolumn{2}{c}{ Rataan } & \multicolumn{1}{c}{$\begin{array}{c}\text { Standar } \\
\text { deviasi }\end{array}$} \\
\cline { 2 - 3 } PAUD & & \multicolumn{1}{c}{$\%$} & \\
Pendidikan & $74.763,44$ & 11,52 & $26.530,75$ \\
Kesehatan & $16.944,33$ & 2,61 & $24.300,49$ \\
Lainnya & $43.854,25$ & 6,76 & $74.892,59$ \\
Total & $119.393,11$ & 18,39 & $82.108,28$ \\
\hline SD & & & \\
Pendidikan & $65.226,25$ & 10,05 & $23.279,93$ \\
Kesehatan & $9.666,58$ & 1,49 & $9.134,09$ \\
Lainnya & $8.052,40$ & 1,24 & $4.084,68$ \\
Total & $75.879,12$ & 11,69 & $24.968,80$ \\
\hline SMP & & & \\
Pendidikan & $87.212,60$ & 13,44 & $33.525,11$ \\
Kesehatan & $6.875,00$ & 1,06 & $3.750,00$ \\
Lainnya & $12.143,82$ & 1,87 & $6.445,36$ \\
Total & $98.999,16$ & 15,25 & $39.712,84$ \\
\hline SMA & & & \\
Pendidikan & $270.411,40$ & 41,66 & $145.917,80$ \\
Kesehatan & $5.083,25$ & 0,78 & $3.500,05$ \\
Lainnya & $10.076,89$ & 1,55 & $3.978,56$ \\
Total & $282.747,60$ & 43,56 & $146.408,80$ \\
\hline
\end{tabular}

Alokasi Uang. Alokasi uang untuk anak terdiri atas alokasi uang untuk memenuhi kebutuhan pendidikan, kesehatan dan kebutuhan lain-lain. Alokasi rata-rata pengeluaran keluarga untuk anak adalah Rp105.860,80/anak/bulan. Hasil penelitian menunjukkan bahwa pengeluaran keluarga untuk anak bervariasi sesuai dengan jenjang pendidikan anak. Keluarga dengan anak SMA memiliki alokasi pengeluaran terbesar yaitu 43,56 persen dari pendapatan keluarga.

\section{Variabel-variabel yang Berpengaruh terhadap Kesejahteraan Keluarga}

Variabel-variabel yang mempengaruhi kesejahteraan keluarga di-analisis menggunakan analisis regresi logistik. Hasil analisis regresi logistik pada Tabel 6 menunjukkan bahwa nilai Negelkerke $R^{2}$ model sebesar 0,332 untuk indikator GK dan 0,560 untuk indikator BLT. Artinya, model dapat menjelaskan sebesar 33,2 persen dan 56,00 persen variabel-variabel yang berpengaruh terhadap kesejahteraan berdasar-kan indikator GK dan BLT. Berdasarkan uji regresi logistik, pekerjaan tambahan suami dan mata pencaharian suami berpengaruh signifikan terhadap indikator GK. Sementara itu, pendidikan suami, mata pencaharian suami, dan pendapatan keluarga berpengaruh signifikan terhadap kesejahteraan keluarga berdasarkan indikator BLT.

Analisis regresi menunjukkan bahwa kesejahteraan keluarga berdasarkan indikator garis kemiskinan dipengaruhi oleh pekerjaan tambahan suami $(\beta=2,190, p<0,05)$ dan mata pencaharian suami $(\beta=2,190, p<0,01)$. Hasil ini menunjukkan bahwa suami yang memiliki pekerjaan tambahan dan bermatapencaharian bukan sebagai petani memiliki peluang untuk menjadi keluarga yang tidak miskin berdasarkan indikator garis kemiskinan.

Tabel 6 Nilai koefisien regresi logistik variabelvariabel yang mempengaruhi kesejahteraan

\begin{tabular}{|c|c|c|c|}
\hline Variabel independen & $\mathrm{B}$ & $\operatorname{Exp}(B)$ & Sig \\
\hline \multicolumn{4}{|c|}{ esejahteraan keluarga berdasarkan indikator GK } \\
\hline Constanta & 3,636 & $-0,026$ & 0,243 \\
\hline ur suami (tahun) & 0,029 & 1,029 & 0,53 \\
\hline $\begin{array}{l}\text { nlah anggota } \\
\text { uarga (orang) }\end{array}$ & 0,110 & 1,117 & $0,6 \mathrm{~s}$ \\
\hline didikan istri (tahun) & 0,062 & 1,064 & 0,7 \\
\hline $\begin{array}{l}\text { ndidikan suami } \\
\text { hun) }\end{array}$ & 0,088 & $-0,916$ & 0,6 \\
\hline $\begin{array}{l}\text { kerjaan tambahan } \\
\text { ami ( } 0=\text { tidak } \\
\text { emiliki; } 1=\text { memiliki) }\end{array}$ & 3,171 & 23,837 & \\
\hline $\begin{array}{l}\text { ata pencaharian } \\
\text { ami ( } 0=\text { pertanian; } \\
\text { bukan pertanian) }\end{array}$ & 2,190 & 8,933 & \\
\hline $\begin{array}{l}\text { pe keluarga } \\
=\text { =keluarga inti; } \\
\text { =keluarga luas) }\end{array}$ & $1,692^{-}$ & $-0,184$ & 0,1 \\
\hline i-square & & 17,396 & \\
\hline gelkerke $\mathrm{R}^{2}$ & & $0,332^{* *}$ & \\
\hline
\end{tabular}

Kesejahteraan keluarga berdasarkan indikator BLT

\begin{tabular}{|c|c|c|c|}
\hline Konstanta & 8,484 & $-0,000$ & 0,025 \\
\hline Umur suami (tahun) & 0,016 & 1,016 & 0,733 \\
\hline $\begin{array}{l}\text { Jumlah anggota } \\
\text { keluarga (orang) }\end{array}$ & 0,410 & $-0,664$ & 0,283 \\
\hline Pendidikan istri (tahun) & 0,197 & 1,218 & 0,378 \\
\hline $\begin{array}{l}\text { Pendidikan suami } \\
\text { (tahun) }\end{array}$ & 0,933 & 2,541 & 0,003 \\
\hline $\begin{array}{l}\text { Pekerjaan tambahan } \\
\text { suami }(0=\text { tidak } \\
\text { memiliki; } 1=\text { memiliki) }\end{array}$ & 0,735 & $-0,479$ & 0,690 \\
\hline $\begin{array}{l}\text { Mata pencaharian } \\
\text { suami }(0=\text { pertanian; } \\
1=\text { bukan pertanian })\end{array}$ & 1,465 & 4,325 & $\begin{array}{r}0,061 \\
*\end{array}$ \\
\hline $\begin{array}{l}\text { Tipe keluarga } \\
\text { (0=keluarga inti; } \\
1=\text { keluarga luas) }\end{array}$ & 0,531 & $-0,588$ & 0,616 \\
\hline $\begin{array}{l}\text { Pendapatan keluarga } \\
\text { (rupiah) }\end{array}$ & 0,000 & 1,000 & 0,004 \\
\hline Chi-square & & 35,854 & \\
\hline Nagelkerke $\mathrm{R}^{2}$ & & $0,560^{* *}$ & \\
\hline
\end{tabular}




\section{Variabel-variabel yang Berpengaruh terhadap Strategi Koping}

Hasil uji regresi linier berganda pada Tabel 7 menunjukkan nilai Adjusted $R$ square sebesar 0,097 . Artinya model ini hanya menjelaskan sebesar 9,7 persen pengaruh variabel-variabel yang ada dalam model terhadap strategi koping yang dilakukan oleh keluarga buruh pemetik melati gambir. Meskipun kecil, jumlah anggota keluarga, tipe keluarga, pekerjaan tambahan suami dan kesejahteraan keluarga berpengaruh signifikan terhadap strategi koping.

\section{Variabel-variabel yang Berpengaruh terhadap Invetasi Anak}

Berdasarkan hasil uji regresi linier berganda diperoleh nilai Adjusted $R$ square sebesar 0,111. Artinya sebesar 11,1 persen variabel yang mempengaruhi perilaku investasi anak dapat dijelaskan oleh model. Pendidikan istri dan pendapatan keluarga berpengaruh signifikan positif terhadap perilaku investasi anak (Tabel 8). Perilaku investasi anak meningkat seiring meningkatnya pendidikan istri dan pendapatan keluarga.

Tabel 7 Nilai koefisien regresi linier variabelvariabel yang mempengaruhi jumlah strategi koping

\begin{tabular}{|c|c|c|c|}
\hline \multirow[b]{2}{*}{ Variabel } & \multicolumn{3}{|c|}{ Koefisien $\beta$} \\
\hline & $\begin{array}{c}\text { Tidak } \\
\text { terstan } \\
\text { darisasi } \\
\end{array}$ & $\begin{array}{l}\text { Terstan } \\
\text { darisasi }\end{array}$ & Sig \\
\hline Konstanta & 10,688 & & 0,000 \\
\hline $\begin{array}{l}\text { Jumlah anggota } \\
\text { keluarga (orang) }\end{array}$ & 0,645 & 0,255 & 0,096 \\
\hline $\begin{array}{l}\text { Pendidikan istri } \\
\text { (tahun) }\end{array}$ & $-0,034$ & $-0,017$ & 0,894 \\
\hline $\begin{array}{l}\text { Pendidikan suami } \\
\text { (tahun) }\end{array}$ & 0,186 & 0,101 & 0,498 \\
\hline $\begin{array}{l}\text { Tipe keluarga } \\
\text { (0=keluarga inti, } \\
1=\text { keluarga luas) }\end{array}$ & $-2,720$ & $-0,299$ & $\begin{array}{l}0,035 \\
* *\end{array}$ \\
\hline $\begin{array}{l}\text { Pekerjaan } \\
\text { tambahan suami } \\
(0=\text { tidak memiliki, } \\
1=\text { =memiliki) }\end{array}$ & 3,068 & 0,216 & $\begin{array}{l}0,095 \\
*\end{array}$ \\
\hline $\begin{array}{l}\text { Pendapatan } \\
\text { keluarga (rupiah) }\end{array}$ & $-2,447 \mathrm{E}-7$ & $-0,035$ & 0,814 \\
\hline $\begin{array}{l}\text { Kesejahteraan } \\
\text { BLT }(0=\text { tidak } \\
\text { sejahtera, } \\
1=\text { sejahtera })\end{array}$ & $-2,169$ & $-0,319$ & $\underset{* *}{0,034}$ \\
\hline$F$ & & $1,995^{*}$ & \\
\hline $\mathrm{R}$ & & 0,440 & \\
\hline $\begin{array}{l}\text { Adjusted R } \\
\text { square }\end{array}$ & & 0,097 & \\
\hline $\begin{array}{l}\text { Keterangan : } \\
* \quad \text { signifikan pada } \\
{ }^{* * *} \text { signifikan pada }\end{array}$ & $\begin{array}{l}1 ;{ }^{* *} \mathrm{~s} \\
01\end{array}$ & & \\
\hline
\end{tabular}

Tabel 8 Nilai koefisien regresi linier faktor-faktor yang mempengaruhi perilaku investasi anak

\begin{tabular}{|c|c|c|c|}
\hline \multirow[b]{2}{*}{ Variabel } & \multicolumn{3}{|c|}{ Koefisien $\beta$} \\
\hline & $\begin{array}{c}\text { Tidak } \\
\text { terstan } \\
\text { darisasi }\end{array}$ & $\begin{array}{l}\text { Terstan } \\
\text { darisasi }\end{array}$ & Sig \\
\hline Konstanta & 28,81 & - & 0,001 \\
\hline $\begin{array}{l}\text { Jumlah anggota } \\
\text { keluarga (orang) }\end{array}$ & $-0,28$ & $-0,04$ & 0,813 \\
\hline $\begin{array}{l}\text { Pendidikan istri } \\
\text { (tahun) }\end{array}$ & 1,92 & 0,29 & $0,020^{* *}$ \\
\hline $\begin{array}{l}\text { Pendidikan } \\
\text { suami (tahun) }\end{array}$ & $-0,19$ & $-0,03$ & 0,804 \\
\hline $\begin{array}{l}\text { Tipe keluarga } \\
\text { (0=keluarga inti, } \\
1=\text { keluarga luas })\end{array}$ & $-6,06$ & $-0,21$ & 0,133 \\
\hline $\begin{array}{l}\text { Pendapatan } \\
\text { keluarga } \\
\text { (rupiah) }\end{array}$ & $5,35 \mathrm{E}-6$ & 0,24 & $0,059^{*}$ \\
\hline $\mathrm{F}$ & & 2,616 & \\
\hline $\mathrm{R}$ & & 0,423 & \\
\hline $\begin{array}{l}\text { Adjusted } R \\
\text { square }\end{array}$ & & $0,111^{* *}$ & \\
\hline
\end{tabular}

\section{Variabel-variabel yang Berpengaruh terhadap Alokasi Uang}

Variabel-variabel yang disusun dalam model dapat menjelaskan 46,9 persen pengaruhnya terhadap alokasi uang untuk anak. Hasil analisis menunjukkan bahwa jumlah anggota keluarga, jumlah anak sekolah, pendidikan suami, tipe keluarga dan pendapatan keluarga memiliki pengaruh yang signifikan terhadap alokasi uang untuk anak pada keluarga buruh pemetik melati gambir (Tabel 9). Jumlah anggota keluarga memiliki hubungan negatif signifikan terhadap alokasi uang untuk anak. Semakin banyak jumlah anggota keluarga, maka akan semakin kecil alokasi uang yang diterima oleh masing-masing anggota keluarga. Banyaknya anak sekolah akan membuat pengeluaran orang tua untuk anak semakin tinggi, baik untuk kebutuhan pendidikan, kesehatan maupun kebutuhan lainlain. Diantara pendidikan orang tua, pendidikan suami lebih berpengaruh secara signifikan terhadap alokasi uang dibandingkan dengan pendidikan istri. Tipe keluarga memiliki pengaruh signifikan positif terhadap alokasi uang untuk anak, keluarga luas memiliki alokasi uang yang lebih banyak dibandingkan dengan keluarga inti. Sementara itu, pendapatan keluarga berpengaruh signifikan positif terhadap alokasi uang untuk anak. Semakin tinggi pendapatan keluarga, maka alokasi uang yang diberikan untuk anak semakin besar. 
Tabel 9 Koefisein regresi karakteristik keluarga dan kesejahteraan terhadap alokasi uang untuk anak

\begin{tabular}{|c|c|c|c|}
\hline \multirow[b]{2}{*}{ Variabel } & \multicolumn{3}{|c|}{ Koefisien $\beta$} \\
\hline & $\begin{array}{l}\text { Tidak } \\
\text { terstan- } \\
\text { darisasi }\end{array}$ & $\begin{array}{l}\text { Terstan- } \\
\text { darisasi }\end{array}$ & Sig \\
\hline \multicolumn{4}{|l|}{ Pengeluaran (Rp) } \\
\hline Konstanta & $-23.656,961$ & - & 0,763 \\
\hline $\begin{array}{l}\text { Jumlah anggota } \\
\text { keluarga (orang) }\end{array}$ & $-41.664,834$ & $-0,476$ & $0,001^{* * *}$ \\
\hline $\begin{array}{l}\text { Jumlah anak } \\
\text { sekolah (orang) }\end{array}$ & $139.104,665$ & 0,778 & $0,000^{* * *}$ \\
\hline $\begin{array}{l}\text { Pendidikan istri } \\
\text { (tahun) }\end{array}$ & $-8.637,462$ & $-0,124$ & 0,228 \\
\hline $\begin{array}{l}\text { Pendidikan suami } \\
\text { (tahun) }\end{array}$ & $20.734,275$ & 0,325 & $0,002^{* * *}$ \\
\hline $\begin{array}{l}\text { Tipe keluarga } \\
\text { (0=keluarga inti, } \\
1=\text { keluarga luas) }\end{array}$ & $77.265,123$ & 0,245 & $0,055^{*}$ \\
\hline $\begin{array}{l}\text { Pendapatan } \\
\text { keluarga (rupiah) }\end{array}$ & 0,078 & 0,320 & $0,003^{* * *}$ \\
\hline $\begin{array}{l}\text { Perilaku Investasi } \\
\text { (skor) }\end{array}$ & 682,388 & 0,063 & 0,554 \\
\hline$F$ & \multicolumn{3}{|c|}{$9,187^{* * *}$} \\
\hline $\mathrm{R}$ & \multicolumn{3}{|c|}{0,725} \\
\hline Adjusted R square & \multicolumn{3}{|c|}{0,469} \\
\hline
\end{tabular}

\section{PEMBAHASAN}

Hasil penelitian ini menegaskan bahwa istri yang bekerja sebagai buruh pemetik melati gambir memiliki kontribusi sebesar 20,64 persen terhadap pendapatan keluarga. Hasil ini mendukung pernyataan Suryocondro (1987), diacu dalam Suryawati (2002) bahwa setiap wanita bekerja di luar rumah dapat membawa dampak positif terhadap pendapatan keluarga. Selain suami dan istri, anak juga memiliki kontribusi terhadap pendapatan keluarga. Penelitian menemukan bahwa penggunaan pendapatan istri sebagai buruh pemetik melati paling banyak digunakan untuk membeli kebutuhan pokok. Pemanfaatan selanjutnya adalah untuk biaya pendidikan anak (uang saku) dan membayar hutang.

Kesejahteraan keluarga berdasarkan dua indikator yang telah digunakan menunjukkan perbedaan jumlah keluarga miskin. Perbedaan hasil ini diduga disebabkan oleh tiga hal. Pertama, indikator BLT memiliki dimensi lebih luas dan lebih menjelaskan kondisi kehidupan dari berbagai aspek seperti ekonomi, pendidikan, kesehatan, dan sosial kemasyarakatan (Muflikhati et al., 2010). Kedua, terdapat tiga indikator yang tidak dipenuhi oleh seluruh keluarga responden di wilayah penelitian yaitu sumber penerangan, kemampuan makan/hari dan kemampuan membayar biaya pengobatan. Ketiga, menurut Muflikhati (2010) kriteria yang ditetapkan terlalu banyak untuk menggolongkan rumah tangga menjadi hampir miskin yaitu sembilan kriteria.

Variabel mata pencaharian suami secara konsisten berpengaruh terhadap status kesejahteraan, baik indikator GK maupun indikator BLT. Keluarga dengan suami yang bekerja di bidang bukan pertanian memiliki peluang yang lebih besar untuk sejahtera dibandingkan dengan keluarga dengan suami yang memiliki pekerjaan di bidang pertanian. Menurut hasil penelitian Sitorus et al. (2008), menurunnya peluang petani untuk meningkatkan kesejahteraan dikarenakan oleh semakin banyaknya kebutuhan petani yang harus dibeli di pasar (semakin komersil) dan input produksi usaha tani yang harus dibeli di pasar (semakin komersil). Akibatnya, banyak keluarga yang mencari pekerjaan di luar bidang pertanian untuk dapat meningkatkan pendapatan keluarga.

Pekerjaan tambahan suami berpengaruh signifikan terhadap kesejahteraan berdasarkan indikator GK. Keluarga dengan suami yang memiliki pekerjaan tambahan berpeluang lebih besar untuk sejatera, dibandingkan dengan keluarga dengan suami yang tidak memiliki pekerjaan tambahan. Adanya pekerjaan tambahan yang dimiliki oleh suami menyebabkan pendapatan keluarga menjadi lebih besar

Pendidikan suami dan pendapatan keluarga berpengaruh signifikan terhadap kesejahteraan berdasarkan indikator BLT. Semakin tinggi pendidikan suami, peluang keluarga untuk sejahtera semakin besar. Pendidikan tinggi membuka peluang suami untuk mendapatkan pekerjaan yang lebih baik dan pendapatan yang lebih tinggi. Hasil ini mendukung penelitian Rambe (2004) dan Muflikhati (2010) bahwa pendidikan kepala keluarga memiliki pengaruh yang signifikan terhadap kesejahteraan keluarga. Semakin tinggi pendapatan keluarga, peluang keluarga untuk sejahtera akan semakin besar. Keluarga dengan pendapatan tinggi akan lebih mampu memenuhi kebutuhan anggota keluarga baik untuk kebutuhan pangan ataupun nonpangan. Hasil penelitian ini mendukung penelitian Iskandar (2007), Aniri (2008), dan Muflikati (2010) bahwa pendapatan berpengaruh signifikan terhadap kesejahteraan keluarga. 
Ketika keluarga mengalami penurunan pendapatan yaitu saat harga bunga melati turun, diperlukan upaya strategi koping untuk dapat memenuhi kebutuhan seluruh anggota keluarga. Menurut Voydanoff (1987), strategi koping adalah proses yang dilakukan oleh individu dan keluarga dalam menggunakan sumber daya yang dimiliki untuk mengatasi kesulitan ekonomi. Secara keseluruhan, strategi koping yang dilakukan oleh keluarga pemetik melati di Desa Gelang sebagian besar termasuk dalam kategori sedikit baik dalam cutting back maupun generating income. Sedikitnya jumlah cutting back menandakan bahwa keluarga buruh pemetik melati telah berusaha meminimalkan kegiatan mengurangi pengeluaran agar tidak terjadi penurunan kualitas hidup. Menurut Puspitawati (1998), tingkat kemiskinan berhubungan erat dengan cutting back dibandingkan dengan generating income.

Kegiatan cutting back lebih mudah untuk dijalankan daripada kegiatan generating income, karena kegiatan generating income melibatkan sumber daya yang dimiliki oleh keluarga seperti SDM dan jejaring yang dimiliki oleh keluarga untuk meningkatkan sumber daya uang. Sementara itu, kegiatan cutting back lebih mudah dijalankan karena dalam pelaksanaannya tidak melibatkan orang lain (jejaring sosial), yaitu hanya melibatkan anggota keluarga. Akan tetapi, sedikitnya jumlah generating income yang dilakukan oleh keluarga berarti keluarga cenderung pasif menghadapi kenyataan. Selain itu, dikarenakan kurangnya akses dan sedikitnya pengetahuan yang dimiliki oleh keluarga sehingga kurang mampu mengeksplor sumber daya yang ada.

Jumlah anggota keluarga, tipe keluarga, pekerjaan tambahan suami, dan pendapatan keluarga berpengaruh signifikan terhadap strategi koping keluarga buruh pemetik melati gambir. Jumlah anggota keluarga memiliki pengaruh positif terhadap jumlah strategi koping. Semakin banyak jumlah anggota keluarga, strategi koping yang dilakukan oleh keluarga akan semakin meningkat. Strategi koping yang dilakukan oleh keluarga untuk memenuhi kebutuhan, khususnya dalam pemenuhan kebutuhan pangan akan semakin sering dilakukan dengan bertambahnya jumlah anggota keluarga (Rachmawati, 2010).

Hasil penelitian lain juga menemukan bahwa tipe keluarga berpengaruh negatif terhadap strategi koping. Keluarga luas memiliki strategi koping yang lebih sedikit dibandingkan dengan keluarga inti. Hal ini kemungkinan terjadi karena keluarga luas yang mendapat tambahan anggota keluarga dianggap lebih sejahtera, sehingga muncul anggota keluarga lain selain keluarga inti yang tinggal bersama dengan keluarga inti. Selain itu, adanya pekerjaan tambahan yang dimiliki suami menunjukkan sebagai salah satu strategi koping menambah pendapatan yang dimiliki oleh keluarga.

Selanjutnya, strategi koping dipengaruhi oleh status kesejahteraan keluarga. Semakin sejahtera, strategi koping yang dilakukan keluarga akan semakin sedikit. Keluarga sejahtera mampu memenuhi kebutuhan keluarga baik kebutuhan pangan maupun nonpangan, sehingga ketika terjadi penurunan pendapatan, keluarga dapat menggunakan sumber daya yang dimiliki untuk mengatasinya, seperti penggunaan aset. Hasil penelitian ini mendukung penelitian Rachmawati (2010) bahwa keluarga yang lebih sejahtera akan memiliki masalah ekonomi yang lebih sedikit dibandingkan dengan keluarga miskin. Strategi koping sebagai upaya untuk mempertahankan kesejahteraan yang merupakan tujuan keluarga tidak saja dipengaruhi oleh faktor dari dalam (endogenous), tetapi ada faktor lain dari luar (eksogenous) yang turut mempengaruhi proses tersebut (Mardiharini, 2002).

Menurut Deacon dan Firebaugh (1988), modal manusia adalah segala kemampuan manusia dan cara penggunaan sumber daya manusia, yang berpengaruh terhadap sumber daya di masa yang akan datang. Berdasarkan hasil penelitian, perilaku investasi pendidikan lebih baik daripada perilaku investasi kesehatan. Hal ini karena orang tua cenderung melakukan tindakan-tindakan yang menjadi keharusan bagi orang tua untuk anak, seperti membayar uang pendidikan. Kegiatan yang membutuhkan biaya tambahan seperti mengajak anak berekreasi dan memberikan ketrampilan khusus atau les jarang dilakukan. Hartoyo dan Hastuti (2003) menyatakan bahwa rendanya pengeluaran untuk pendidikan anak memungkinkan anak kurang dapat mengembangkan potensinya. Oleh karenanya, temuan menarik dari penelitian ini adalah meskipun sebagian besar keluarga berada pada kategori miskin namun kesadaran orang tua mengembangkan potensi melalui investasi pendidikan sudah cukup baik.

Keluarga dalam penelitian ini memiliki perilaku investasi kesehatan pada kategori sedang bahkan rendah. Berdasarkan hasil penelitian BPS (2009), kesadaran masyarakat Indonesia terhadap kesehatan masih tergolong rendah. Perilaku investasi kesehatan yang 
paling sering dilakukan adalah tindakan kuratif yaitu saat anak sakit. Keluarga jarang sekali melakukan kegiatan preventif atau pencegahan. Orang tua merasa memberikan pelayanan kepada anak seperti pemberian makanan bergizi, vitamin, dan lain-lain membutuhkan biaya yang tinggi. Sementara itu, pendapatan keluarga sudah habis dimanfaatkan untuk memenuhi kebutuhan pangan dan kebutuhan dasar lainnya. Bryant dan Zick (2006) menyatakan bahwa investasi kesehatan memiliki biaya tambahan yang lebih rumit dibandingkan dengan investasi pendidikan. Rendahnya perilaku investasi yang dilakukan orang tua dapat terjadi karena pendidikan orang tua yang rendah, sehingga orang tua menganggap anak bukan untuk investasi sebagai perbaikan kualitas SDM tapi sebagai tenaga kerja yang murah dan sebagai sandaran hidup di hari tua.

Pendidikan ibu dan pendapatan keluarga berpengaruh signifikan terhadap perilaku investasi anak. Istri dengan pendidikan lebih tinggi akan memiliki pengetahuan yang lebih baik, sehingga perilaku investasi yang dilakukan terhadap anak akan semakin tingggi. Hasil ini mendukung penelitian Leibowitz (1982) bahwa pendidikan istri berhubungan signifikan terhadap IQ anak. Hasil ini mengindikasikan bahwa investasi yang dilakukan lebih berdasarkan pada hubungan antara anak dengan ibu dibandingkan dengan faktor genetik yang diturunkan oleh ibu. Pendapatan keluarga berpengaruh signifikan terhadap perilaku investasi anak. Semakin tinggi pendapatan, perilaku investasi akan semakin baik. Keluarga dengan pendapatan tinggi diasumsikan dengan pemenuhan kebutuhan pangan yang telah tercukupi. Menurut Shinta (2008) seiring dengan meningkatnya pendapatan keluarga, maka pemenuhan kebutuhan keluarga setelah pangan akan diprioritaskan untuk kebutuhan pendidikan dan kesehatan.

Investasi anak selain diukur berdasarkan perilaku, juga diukur berdasarkan alokasi uang yang diberikan oleh orang tua untuk anak. Alokasi uang untuk anak adalah semua pengeluaran yang manfaatnya dirasakan oleh anak secara langsung, mulai untuk makan, pendidikan, kesehatan dan pengeluaran lainnya (Hartoyo \& Hastuti, 2003). Dalam penelitian ini, alokasi uang untuk makan tidak dihitung, karena kebutuhan makan untuk anak masih bersama dengan orang tua. Alokasi uang ini bervariasi tergantung pada tingkat pendidikan anak dan jumlah anak yang dimiliki keluarga. Berdasarkan hasil penelitian, keluarga yang memiliki anak SMA memiliki alokasi uang paling besar dibandingkan dengan keluarga dengan anak PAUD, SD dan SMP. Menurut Lino (2009), biaya tahunan yang dikeluarkan untuk anak secara umum meningkat sesuai dengan bertambahnya umur anak.

Besarnya alokasi uang untuk anak dipengaruhi oleh jumlah anggota keluarga, jumlah anak sekolah, pendidikan suami, tipe keluarga, dan pendapatan keluarga. Semakin banyak jumlah anggota keluarga, alokasi uang yang diterima oleh masing-masing anggota keluarga akan semakin kecil. Bertambahnya jumlah anggota keluarga akan menambah beban kepala keluarga untuk memenuhi kebutuhan anggota keluarga. Hasil ini mendukung penelitian Hartoyo (1998) bahwa jumlah anggota keluarga memiliki pengaruh negatif terhadap investasi anak dalam bentuk uang. Leibowitz (1982) menyatakan bahwa penambahan jumlah anggota keluarga akan mengurangi dukungan keluarga terhadap anak dalam penentuan sekolah karena adanya kesulitan keuangan dan hal ini mengindikasikan tingkatan yang rendah dalam investasi keluarga.

Banyaknya anak sekolah akan menambah pengeluaran orang tua untuk anak. Semakin tinggi pendidikan suami, alokasi uang untuk anak akan semakin besar. Hal ini diduga karena suami adalah pengatur keuangan rumah tangga, sehingga pengambil keputusan pengeluaran masih didominasi oleh suami. Selain itu, semakin tinggi pendidikan suami akan membuat orientasi anak menjadi lebih penting (Permatasari, 2010).

Semakin tinggi pendapatan keluarga, alokasi uang yang diberikan untuk anak akan semakin besar. Keluarga dengan pendapatan tinggi akan lebih mencurahkan sumber daya yang dimiliki untuk meningkatkan kualitas anak (Hartoyo, 1998). Berdasarkan hasil penelitian Yeung, Linver, dan Brooks-Gun (2002), tingkat dan stabilitas pendapatan keluarga memiliki pengaruh yang jelas terhadap fungsi keluarga dan kesejahteraan anak.

Hasil penelitian juga menemukan bahwa keluarga luas memiliki alokasi uang yang lebih besar dibandingkan dengan keluarga inti. Hasil ini berbeda dengan Suryawati (2002) bahwa keluarga inti memberikan alokasi pendidikan lebih banyak dibandingkan dengan keluarga luas. Perbedaan ini kemungkinan dapat terjadi karena keluarga luas, misalnya hadirnya kakak ipar atau nenek/kakek dalam keluarga turut berpartisipasi terhadap alokasi uang yang diberikan untuk anak. Hasil penelitian tidak menunjukkan bahwa perilaku investasi memiliki 
pengaruh terhadap alokasi pengeluaran uang untuk anak. Pada dasarnya semua orang tua menginginkan kehidupan yang lebih baik untuk anak-anaknya. Akan tetapi, keterbatasan sumber daya materi seperti uang dan pengetahuan yang dimiliki orang tua membuat orang tua kurang memperhatikan segala kebutuhan anak untuk meningkatkan kualitas SDM.

\section{SIMPULAN DAN SARAN}

Istri memiliki kontribusi pendapatan terkecil terhadap pendapatan keluarga dibandingkan dengan suami dan anak yang bekerja. Berdasarkan indikator BPS, keluarga buruh pemetik melati gambir lebih banyak tergolong keluarga miskin dibandingkan dengan indikator BLT. Secara keseluruhan, strategi koping yang dilakukan oleh keluarga temasuk dalam kategori sedikit ketika mengalami penurunan pendapatan keluarga baik dalam kegiatan cutting back maupun generating income. Perilaku investasi yang dilakukan oleh keluarga termasuk dalam kategori sedang dengan perilaku investasi pendidikan lebih baik dibandingkan dengan perilaku investasi kesehatan. Akan tetapi, alokasi uang untuk anak termasuk dalam kategori rendah berdasarkan rata-rata alokasi uang secara keseluruhan yang dikeluarkan oleh keluarga buruh pemetik melati gambir.

Kesejahteraan keluarga dipengaruhi oleh pekerjaan tambahan suami, mata pencaharian suami, pendidikan suami, dan pendapatan keluarga. Jumlah anggota keluarga, tipe keluarga, pekerjaan tambahan suami, dan kesejahteraan keluarga memiliki pengaruh yang signifikan terhadap jumlah strategi koping keluarga. Pendidikan istri dan pendapatan keluarga memiliki pengaruh positif signifikan terhadap perilaku investasi anak, sedangkan jumlah anggota keluarga, jumlah anak sekolah, pendidikan suami, tipe keluarga dan pendapatan keluarga memiliki pengaruh signifikan terhadap alokasi uang untuk anak.

Berdasarkan hasil, penelitian ini menyarankan adanya program peningkatan kesejahteraan keluarga melalui penyediaan/penciptaan lapangan kerca. Program kesejahteraan ini hendaknya dibarengi dengan program lain yang berupaya untuk mengurangi angka kelahiran dan pengendalian penduduk yaitu peningkatan kembali pemasaran sosial program Keluarga Berencana (KB). Selain itu, diperlukan juga program yang memberikan kemudahan akses terhadap fasilitas yang diarahkan untuk investasi pendidikan dan kesehatan, sehingga keluarga miskin mampu memiliki anak yang berkualitas.

\section{DAFTAR PUSTAKA}

Aniri, N. B. (2008). Analisis Faktor yang Berpengaruh terhadap Tingkat Kesejahhteraan Keluarga Pembudidaya dan Nonpembudidaya Ikan di Kabupaten Bogor [skripsi]. Bogor: Institut Pertanian Bogor.

[BPS]. Badan Pusat Statistik. (2009). Indikator Kesehatan 1995-2009. Diambil dari: http://www.bps.go.id. [diunduh 5 Februari 2011].

(2010). Profil kemiskinan di Indonesia Maret 2010. Diambil dari: http://www.bps.go.id. [diunduh 9 November 2010].

Bryant, W.K., \& Zick, C.D. (2006). The Economic Organization of the Household, Second Edition. Cambridge: Cambridge University Press.

[CPRC] Chronic Poverty Research Centre. The Chronic Poverty Report 2008-09: Escaping Poverty Traps. Manchester: School of Environment and Development, The University of Manchester.

Deacon, R. E., \& Firebaugh, F.M. (1988). Family Resource Management. United State of America: Allymd and Bacon, inc:.

Hartoyo. (1998). Investing in children: study of rural families in Indonesia. [Disertasi]. Blacksburg: Virginia Tech University.

Hartoyo, \& Hastuti, D. (2003). Perilaku Investasi Anak pada Keluarga Nelayan dan Implikasinya terhadap Pengentasan Kemiskinan [Laporan Penelitian]. Bogor: Gizi Masyarakat dan Sumberdaya Keluarga, Institut Pertanian Bogor

Iskandar, A. (2007). Analisis Praktek Manajemen Sumberdaya Keluarga dan Dampaknya terhadap Kesejahteraan Keluarga di Kabupaten dan Kota Bogor [Disertasi]. Bogor: Sekolah Pascasarjana, Institut Pertanian Bogor.

Kusumo, R. A. B. (2009). Peran Gender dalam Strategi Koping dan Pengambilan Keputusan serta Hubungannya dengan Kesejahteraan Keluarga Petani Padi dan Hortikultura Di Daerah Pinggiran Perkotaan [Tesis]. Bogor: Sekolah Pascasarjana, Institut Pertanian Bogor. 
Leibowitz, A. (1982). Home Investment in Children. Schultz TW, editor. Chicago: University of Chicago Press.

Lino, M. (2010). Expenditures on Children by Families 2009. U.S. Department of Agriculture, Center for Nutrition Policy and Promotion. Miscellaneous Publication.

Mardiharini, M. (2002). Upaya Keluarga dalam Mempertahankan Kesejahteraannya Selama Krisis Ekonomi [Tesis]. Bogor: Sekolah Pascasarjana. Institut Pertanian Bogor.

Muflikhati, I. (2010). Analisi dan Pengembangan Model Peningkatan Kualitas Sumberdaya Manusia dan Kesejahteraan Keluarga di Wilayah Pesisir Provinsi Jawa Barat [Disertasi]. Bogor: Sekolah Pascasarjana, Institut Pertanian Bogor.

Muflikhati, I., Hartoyo, Sumarwan, U., Fahrudin, A., \& Puspitawati, H. (2010). Kondisi Sosial Ekonomi dan Tingkat Kesejahteraan Keluarga:Kasus di Wilayah Pesisir Jawa Barat. Jurnal IImu Keluarga dan Konsumen. 3(1).

Permatasari, D. (2010). Pengaruh persepsi pendidikan dan nilai anak terhadap alokasi pengeluaran untuk pendidikan anak [Skripsi]. Bogor: Institut Pertanian Bogor.

Puspitawati, H. (1998). Poverty Level and Conflict Over Money within Families [Thesis]. lowa: lowa State University.

Rachmawati, A. (2010). Strategi Koping dan Faktor-faktor yang Mempengaruhi
Kesejahteraan Subjektif pada Keluarga Penerima Program PKH [Skripsi]. Bogor: Institut Pertanian Bogor.

Rambe, A. (2004). Alokasi Pengeluaran Rumah Tangga dan Tingkat Kesejahteraan [tesis]. Bogor. Sekolah Pasca Sarjana. Institut Pertanian Bogor.

Shinta, Y. (2008). Analisis Alokasi Pengeluaran dan Tingkat Kesejahteraan Masyarakat Pesisir Kabupaten Indramayu [skripsi]. Bogor: Institut Pertanian Bogor.

Sitorus, M. T. F., Dharmawan, A. H., Fadjar, U., \& Sihaloho, M,. (2008). Perubahan Struktur Agraria dan Diferensiasi Kesejahteraan Petani [Laporan Penelitian]. Bogor: Institut Pertanian Bogor kerjasama dengan Badan Penelitian dan Pengembangan Pertanian.

Suryawati. (2002). Alokasi Pengeluaran untuk Pendidikan Anak pada Keluarga lbu Bekerja dan Ibu Tidak Bekerja [Tesis]. Bogor: Sekolah Pascasarjana, Institut Pertanian Bogor.

Todaro, M. P., \& Smith, S. C,. (2006). Pembangunan Ekonomi. Ed 9. Jilid 1. Jakarta: PT Gelora Aksara Pratama.

Voydanoff, P. (1987). Work and Family Life. California: SAGE Publication Inc.

Yeung, W. J., Liver, M. R., \& Brooks-Gunn, J,. (2002). How Money Metters for Young Children's Development: Parental Investment and Family Processes. Journal of Child Development .73. 